Article

\title{
Conservation Value of Residential Open Space: Designation and Management Language of Florida's Land Development Regulations
}

\section{Dara M. Wald * and Mark E. Hostetler}

Department of Wildlife Ecology and Conservation, University of Florida, P.O. Box 110430, Gainesville, FL 32611-0430, USA; E-Mail: hostetm@ufl.edu

* Author to whom correspondence should be addressed; E-Mail: dwald@ufl.edu; Tel.: +1-781-964-5807; Fax: +1-352-392-6984.

Received: 15 April 2010; in revised form: 27 April 2010 / Accepted: 26 May 2010 / Published: 1 June 2010

\begin{abstract}
The conservation value of open space depends upon the quantity and quality of the area protected, as well as how it is designed and managed. This study reports the results of a content analysis of Florida county Land Development Regulations. Codes were reviewed to determine the amount of open space required, how open space is protected during construction, the delegation of responsibilities, and the designation of funds for management. Definitions of open space varied dramatically across the state. Most county codes provided inadequate descriptions of management recommendations, which could lead to a decline in the conservation value of the protected space.
\end{abstract}

Keywords: conservation development; environmental policy; regulations; open space

\section{Introduction}

Throughout the United States, sprawling development patterns consume excessive amounts of land and result in a pattern of haphazardly arranged, unplanned, car-dependent communities [1,2]. Direct results of sprawl include increased pollution and congestion, the loss of farmland and open space, and the destruction of rare habitats [1,3,4]. To combat sprawl, cities and counties are adopting new practices, policies, and solutions that minimize sprawl by emphasizing resource conservation and low impact development techniques as an alternative to conventional suburban development [5]. 
Florida is by no means immune to sprawl or its impacts. Over the next quarter century, an additional 12 million people will become Florida residents [6]. This rapidly increasing human population will spark increased growth, demand for energy, water, and new homes [7]. Florida communities have adopted a number of different methods to manage growth. Typically, these methods include regulations (e.g., required wetland protection) or incentives (e.g., increased development density for natural area protection). The Growth Management Act, adopted in 1985, is one example of a statewide regulatory mechanism designed to manage growth $[8,9]$. The Act requires that each county and city in Florida implement a Comprehensive Plan that includes transportation and housing elements, as well as guidelines for the preservation and protection of open space [8,9]. Florida state statutes require that cities and counties explain "specifically" in a "detailed" manner how they designate and regulate open space [10]. To do this, cities and counties employ Land Development Regulations (LDRs), which explain how the land development elements, included in the comprehensive plan will be implemented locally [8-10].

Open space is one of the many elements addressed in county LDRs. Open space can include natural habitats such as forests, fields, and wetlands as well as areas for passive recreational activities such as biking and walking trails $[11,12]$. The conservation value of open space is contingent on its design (i.e., the quantity or quality of habitat protected), impacts from nearby areas (e.g., subdivisions), and long-term management [12,13]. Here, we define conservation value as protecting natural resources, such as wildlife habitat, water bodies (e.g., streams, lakes, and wetlands), and native plant communities. Policies regulating open space often focus solely on design while neglecting management [14-19]. Without comprehensive policies requiring effective open space management, the conservation value of protected areas may be lost or degraded. Following a review of the challenges of conserving valuable open space, we provide examples of critical elements that maximize the conservation value of protected areas. Finally, we will use a content analysis to explore how Florida county LDRs address open space conservation. This content analysis will identify (1) how much open space is required by each county, (2) how open space is defined, and (3) how much open space management language is included in the LDRs. Because Florida statutes require that LDRs address open space, we expect each county to have a definition of open space. However, because the Florida statue is open to interpretation, we expect open space designation and management requirements to vary greatly between counties. The results of the content analysis will be used to develop an open space index and management index that will enable us to compare the extent to which open space designation and management elements are included in county policies.

\section{Sustainable Development and the Conservation of Open Space}

Recent sustainable development strategies include setting aside open space as part of the subdivision design. If designed and managed properly, this type of development can minimize land degradation, reduce edge effect, and enhance landscape connectivity [3,12,20-23]. Conserving natural areas can combat pollution and protect water quality by minimizing erosion and reducing runoff to local streams and water bodies [3,23]. Open space that connects to existing natural areas can enhance regional connectivity and wildlife habitat by protecting critical areas including wetlands, woodlands, and meadows [3,13,24-27]. Large conservation areas near private subdivisions in Colorado and North 
Carolina provided shelter for large mammals such as ungulates and black bears [28]. In a study of six clustered subdivisions in Boulder, protected areas provided refuge for several native flora and fauna species [13]. Even small areas (1 to $50 \mathrm{ha}$ ), if designed and managed properly, can provide refuge for birds, mammals, reptiles, and insects [29]. However, the design and maintenance depends on the target animals or plants that the open space is intended to conserve [12].

Communally managed open space can provide social benefits as well, encouraging interaction between residents [3]. The presence of open space can increase community-wide quality of life [23], lead to increased property values [24,30], and foster a sense of responsibility for and connection to local natural resources [3]. In Florida, there is widespread support for the protection of natural areas and farmland [4,24,30]. For example, voters approved more than $\$ 42$ million to enhance existing parks and purchase new lands in 2001 [31]. Across the U.S., many homebuyers prefer living in open space communities and are willing to pay premium prices for attractive lots [3,14,24,26,30,32]. The private protection of open space provides municipalities and citizens with the benefit of open space, while minimizing the public cost of purchasing land [32]. Minimizing the development footprint can also diminish development costs in subdivision preparation and infrastructure [25,26,32-34]. As a result, developers can reduce building costs and sell homes more quickly, at a higher price than comparable homes in a traditional development [33,34].

Whether small or large, the degree to which open space protects natural resources and biodiversity depends on the design and management of both the built and conserved areas [12]. Failure to address critical design and management elements can result in the creation of open space areas with little or no conservation value. Without the management of conserved areas, biodiversity can deteriorate due to invasions by exotic species or pest outbreaks $[7,35,36]$. In several urban developments in Colorado, lack of management contributed to high densities of non-native species in the open space areas [13]. Without management, natural habitat can degrade and lose wildlife value over time [12,13]. For example, Florida longleaf pine ecosystems must be burned (depending on local site conditions) every two to four years to prevent oaks and other hardwoods from taking over [37]. Typically, policies and examples of open space protection throughout the U.S. focus primarily on the design of these areas; the long-term management of both built areas and conserved open space is rarely addressed [12,38].

\section{Best Practices for Enhancing the Conservation Value of Open Space}

If a developer or county wishes to protect the conservation value of open space, a number of important design and management elements should be addressed. First, relatively undisturbed natural areas should be identified as part of the upfront subdivision planning and design [11,12]. To prevent the creation of open space with low quality habitat, policies should address the type of natural habitat to be conserved (e.g., high quality wetlands or uplands). Open space should include large and contiguous areas of habitat, and these should connect to protected areas outside of the development footprint [23,39]. In addition, built areas should be clustered in one section of a development, separate from conserved areas [12,13,20,21]. Proximity of human elements can affect the use of open space by sensitive species $[13,21,22]$; for example, the prevalence of sensitive bird species generally declines as proximity to development increases [21]. Finally, appropriate activities and elements within conserved open space should be clearly identified (e.g., no roadway, no pets off leash) [17,26]. 
The management and maintenance of open space within developed areas is critical to achieving the conservation goals of a development $[18,36]$. As such, a variety of management activities may be employed, including prescribed burning, pest control, erosion prevention, restoration of native flora through plantings, managing for specific wildlife populations, and the removal of invasive plants or animals. In situations where native vegetation is lacking and habitat quality is poor, management efforts should include the restoration of native flora to increase biodiversity [12]. Written management plans are important and should provide a clear site description, a statement of intended uses, and goals of various management activities, e.g., enhancing wildlife habitat, preventing the spread of invasive species, and improving water quality [17]. Good management plans can help create functional habitat with higher levels of biodiversity than subdivisions without such plans [12,13,28]. Most management practices require a source of funding; therefore, a good management plan should identify a long-term funding source.

Because nearby built areas can have a significant impact on high quality conserved habitat, management activities should extend beyond the conserved spaces, to the community living within the development [12,13,18]. Homeowners' behaviors, such as the replacement of turf with native vegetation, can reduce the spread of exotic species to natural areas and eliminate the need for pesticides and fertilizer on each individual yard [18,40,41]. Moreover, homeowner activities within the open space, such as allowing free-range dogs or cats, can compromise the ecological integrity of the protected habitat [7,12]. The Town of Harmony in Florida has developed and implemented a management plan that addresses natural resource conservation on both the built and conserved areas (http://www.wec.ufl.edu/extension/gc/harmony/). The developer designated funding for open space management; engaged local residents with environmental education efforts; hired a conservation manager; and wrote a covenants, codes, and restrictions document (CCR) that addressed management issues, including a list of the behaviors appropriate in both the built and conserved areas [42].

\section{Methods - Content Analysis of Florida LDRs}

\subsection{County Selection}

We obtained electronic copies of LDRs from all 67 Florida counties. We removed city LDRs for the purpose of this study. We believe this was appropriate, because the greatest opportunity for open space preservation is in the unincorporated areas of counties. Codes were collected through county offices and the Municode Online Library [43]. Jackson and Baker County LDRs were under review; therefore, drafts of the proposed LDRs were analyzed. Complete electronic versions of the LDRs for Lafayette, Nassau, Dixie, Union and Suwannee counties were not readily available; instead select chapters (subdivision design, zoning, and planned unit developments (PUD) regulations) were analyzed for content.

\subsection{Analyses}

The actual application of land development policy takes place at the local level through LDRs and zoning codes. Therefore, a content analysis of LDR documents should provide an in-depth picture of how county regulations address open space protection and management. Content analyses allow 
researchers to appraise the content of a wide range of sources, including newspaper articles, books, and private document $[44,45]$.

To establish the content analysis categories, we used recommendations from a model ordinance written for Georgia by the Atlanta Regional Council [26], published articles [11-13,21,22,28,38], and a Land Use and Management Plan created by the Commonwealth of Massachusetts Executive Office of Environmental Affairs Division of Conservation Services [17].

The final coding instrument was used to evaluate all sections of the LDRs including zoning and subdivision ordinances. Questions were divided into 3 sections: 16 addressed open space designation, 12 concerned long-term management, and 6 were open-ended questions. The 16-item open space series of questions was collapsed into the Open Space Index (OSI) (Cronbach's $\alpha=0.77$ ). Cronbach's alpha is a measure of scale reliability and internal consistency [46]. The OSI scale measured the degree to which county LDRs designated and defined open space within residential developments. For open space management, the 12 questions concerning management best practices were brought together into the Management Index (MI) (Cronbach's $\alpha=0.84$ ).

The coding instrument included 28 questions; counties scored one point if they addressed a given index question in their policy (for example: does the county have a definition of open space, does it require an open space management plan? $1=$ yes, $0=$ no). Coders were provided with a detailed coding protocol that included definitions of key terms and specific instructions about the possible responses for each question. A priori testing of the coding protocol ensured that all the relevant terms and criteria were listed and comprehensible. We realize that not all items are equal; some may play a more significant role in the designation of open space than others. However, we do not know how much weight to allocate to each item. Therefore, we assigned each of the scale items the same weight. Points were summed to form the Open Space Index (maximum 16 points) and Management Index (maximum 12 points). These were summed to generate a Total Policy score (maximum 28 points). The final six questions were open-ended. Coders identified common concepts or themes used to designate and manage open space. Qualitative themes were extracted.

We trained three coders to define and identify the key terms of interest within the LDRs [44]. After training, the coding instrument and guidelines were reviewed and we redefined terms as needed. For this research, open space included only conserved areas contained within a private residential development. Regulations addressing the protection of natural areas outside of developments, privately or publicly owned areas, including parks, baseball fields, and playgrounds were not evaluated.

A standard level of acceptable agreement between coders is $80 \%$ [44]. To address coding reliability, seven county LDRs from the main sample were randomly selected, scored independently by three coders, and percent agreement was calculated [44,47]. Four questions showed significant deviation between coders. Coders were retrained on those four questions and after retraining, we achieved overall agreement of $89 \%$. Coders scored the remaining counties individually.

To allow for comparison between the scales, the OSI and MI scales were standardized (OSI/16 and MSI/12). We conducted a paired t-test to determine if Open Space Indices differed significantly from Management Indices. A Pearson's r correlation measured the strength of the association between OSI and MI. Finally, we conducted some preliminary explanatory analyses of the various county factors (e.g., population size, total acres conserved by local government, home prices etc.) that might predict high or low Total Policy scores. The total conservation land protected by local government 
(LocCSV) and the percent total county land in conservation (\%LAND) was estimated from the Florida Natural Areas Inventory 2009 (http://www.fnai.org/). Per capita income (INCOME), and voter registration (VOTE) in the 2008 general election were gathered through county websites and the Bureau of Economic and Business Research http://www.bebr.ufl.edu/node/20. LocCSV was measured by acres of total conservation area and this ranged from no areas of conservation area to over 60,000 acres per county. The \%Land was calculated by dividing the LocCSV from the total county area in acres. INCOME ranged from low values $\$ 17,000$ to higher values $\$ 63,000$. Pearson's r correlations were computed to determine the relationships between LocCSV, INCOME, VOTE, POP, \%LAND and the Total Policy Score. For all tests alpha was 0.05.

Figure 1. Combined open space and management index scores (Total Policy Scores) for Florida counties calculated from content analyses.

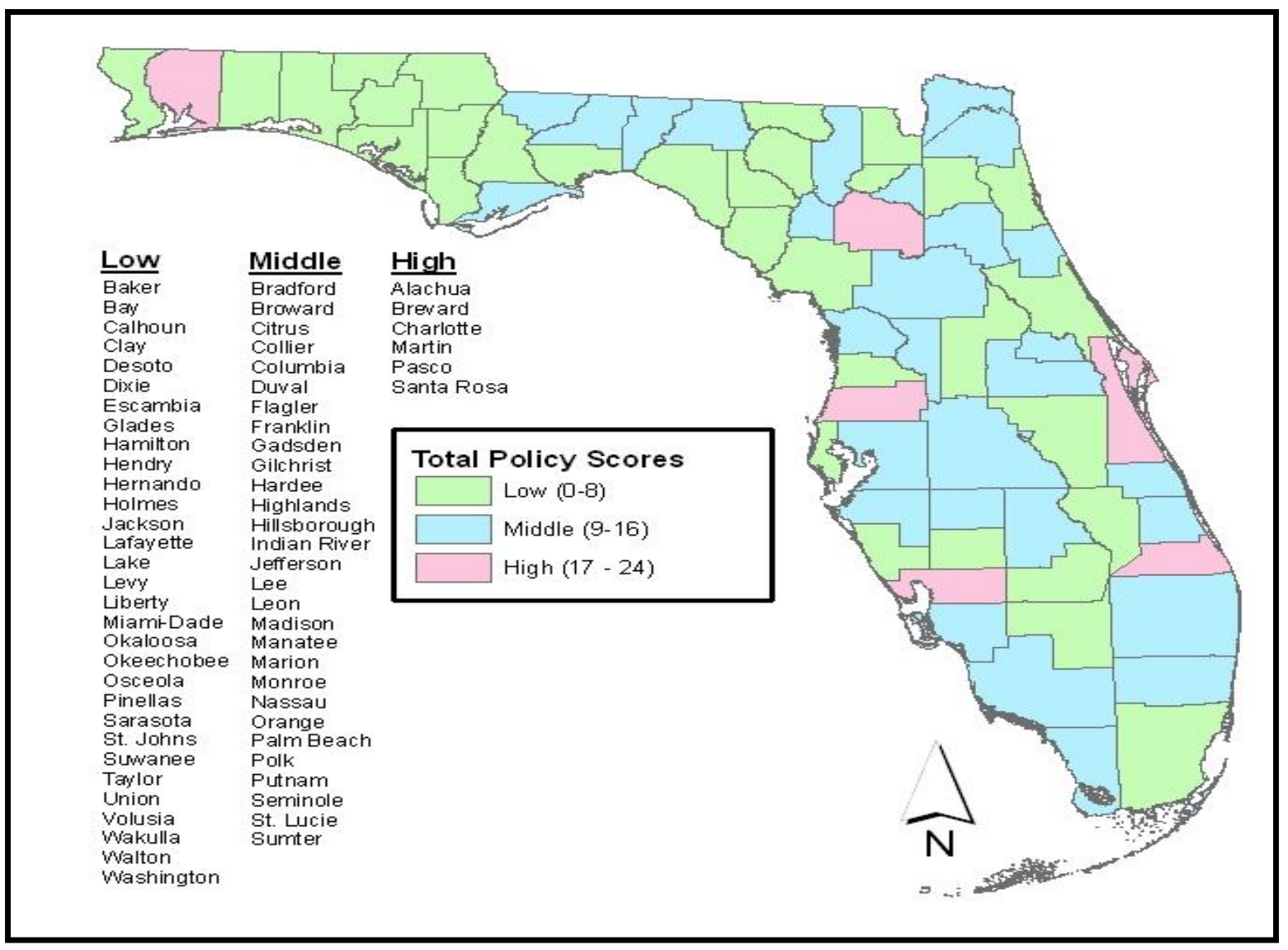

\section{Results}

\subsection{Open Space Designation}

Fifty counties provided a definition of open space (Table 1). However, the definition of open space varied drastically. Some definitions included examples of appropriate land, others mentioned prohibited elements, and still others described them vaguely as areas of undeveloped land. In some counties, the definition of open space included yards and landscaped buffers, while others prohibited the inclusion of required lawns in the open space area. The majority of counties $(91 \%)$ required the 
protection of open space as part of a residential development. Thirty-one counties (46\%) required at least $20 \%$ of the total development area to be protected as open space. Approximately $70 \%$ of the counties provided incentives to developers for protecting natural areas within residential developments and required clear ownership of the open space. However, few counties (16\%) discussed the size, shape or contiguous nature of the protected areas. Half (45\%) of the communities surveyed described appropriate and unacceptable habitat types to preserve as open space (e.g., wetlands, scrub etc.). Less than a quarter $(22 \%)$ of the counties required that open space connect to existing natural areas outside of the development.

There appeared to be little acknowledgement of potential human impacts to the open space during construction and after residents purchase homes. Two of the items least frequently addressed were the proximity of residential structures to the natural area and resident education. Few counties (12\%) prohibited the location of residential structures next to the open space, while only one county (Lee) required residents to participate in educational programs about the value of open space conservation. A quarter of the counties (25\%) mentioned methods of protecting open space during the development process.

Table 1. Questions used for the content analysis and summed results indicating affirmative responses for all Florida counties.

\begin{tabular}{|c|c|c|}
\hline \multirow{2}{*}{\multicolumn{2}{|c|}{ Open Space Designation (16 items)* }} & \multirow{2}{*}{$\begin{array}{l}\text { All Counties } \\
\qquad(\mathrm{N}=67) \\
\mathbf{6 . 9 3 ( 3 . 1 4 ) ^ { \mathrm { a } }}\end{array}$} \\
\hline & & \\
\hline 1 & Does the ordinance define open space? & $50(75)$ \\
\hline 2 & Does it require the preservation of open space as part of development? & $61(91)$ \\
\hline 3 & Does it require that open space be set aside in a contiguous tract of land? & $11(16)$ \\
\hline 4 & Does it provide incentives for the preservation of open space? & $47(70)$ \\
\hline 5 & Does it identify the type of land that must be included in open space? & $30(45)$ \\
\hline 6 & $\begin{array}{l}\text { Does it identify hardscape elements that are not allowed within the } \\
\text { open space? }\end{array}$ & $41(61)$ \\
\hline 7 & $\begin{array}{l}\text { Does it identify recreational elements that are allowed within the } \\
\text { open space? }\end{array}$ & $43(64)$ \\
\hline 8 & Does it include a list of permissible activities? & $39(58)$ \\
\hline 9 & Does it include a list of prohibited activities and uses? & $13(19)$ \\
\hline 10 & $\begin{array}{l}\text { Does it mention activities that protect open space and natural areas } \\
\text { during development? }\end{array}$ & $17(25)$ \\
\hline 11 & Does it require legal protection of the open space? & $31(46)$ \\
\hline 12 & $\begin{array}{l}\text { Does it require that the open-space design connect to existing } \\
\text { community-wide open space }\end{array}$ & $15(22)$ \\
\hline 13 & $\begin{array}{l}\text { Does it require design of open space to account for future land use of } \\
\text { surrounding areas? }\end{array}$ & $10(15)$ \\
\hline 14 & Does it prohibit residential structures that abut the natural area? & $8(12)$ \\
\hline 15 & Does it require education for residents about open space? & $1(1)$ \\
\hline 16 & Does it require clear ownership of the open space? & $43(64)$ \\
\hline
\end{tabular}


Table 1. Cont.

\begin{tabular}{|c|c|c|}
\hline \multirow{2}{*}{\multicolumn{2}{|c|}{ Management of Open Space (12 items)* }} & \multirow{3}{*}{$\begin{array}{l}\text { All Counties } \\
\begin{array}{c}(\mathrm{N}=67) \\
\frac{\mathbf{2 . 3 8}(\mathbf{2 . 6 0})^{\mathrm{a}}}{6(9)}\end{array}\end{array}$} \\
\hline & & \\
\hline 1 & Does it require access to the open space for management? & \\
\hline 2 & Does it require an open space management plan? & $12(18)$ \\
\hline 3 & $\begin{array}{l}\text { Does it require the management plan to identify } \\
\text { maintenance objectives? }\end{array}$ & $4(6)$ \\
\hline 4 & $\begin{array}{l}\text { Does it require that changes to the plan be approved by a } \\
\text { regulatory entity? }\end{array}$ & $3(4)$ \\
\hline 5 & Does it require specifics about who will manage the open space? & $31(46)$ \\
\hline 6 & $\begin{array}{l}\text { Does it address the consequences of failure to manage by the } \\
\text { responsible party? }\end{array}$ & $4(6)$ \\
\hline 7 & Does it require maintenance efforts in the open space? & $37(55)$ \\
\hline 8 & Does it require an estimate for the costs for maintenance activities? & $2(3)$ \\
\hline 9 & Does it require funding for maintenance in perpetuity? & $11(16)$ \\
\hline 10 & Does it require management efforts that enhance local flora? & $15(22)$ \\
\hline 11 & Does it require management efforts that enhance local fauna? & $9(13)$ \\
\hline 12 & $\begin{array}{l}\text { Does it specify a length of time that management activities } \\
\text { will continue? }\end{array}$ & $23(34)$ \\
\hline \multicolumn{2}{|c|}{ Total Policy Score (28 items) } & $9.32(5.17)^{a}$ \\
\hline
\end{tabular}

Numbers in brackets indicate percentage out of the total number of counties.

${ }^{a}$ Mean scores non-standardized for each group of questions: open space, management and total in bold (standard deviation in parentheses).

A fair amount of attention was given to identifying allowable hardscape and recreational elements within the open space with $61 \%$ of the counties mentioning the former and $64 \%$ specifying the later. Responses for allowable and prohibited elements were diverse. More than half of the counties allowed structures and accessories for recreational purposes. Golf courses were addressed in a multitude of contradictory ways. Some counties counted them as open space; two counties (Citrus and Lake) allowed them but specified that accessory structures for active recreation, such as clubhouses, were prohibited. Hillsborough County specified that golf courses could not qualify as open space. A majority of the counties prohibited roads within the open space.

\subsection{Management of Open Space}

The most widely mentioned policy was maintenance of the open space, with more than half (55\%) of the counties addressing this element. In addition, 34\% required developers to specify how long management activities would be provided. Eighteen counties (27\%) mentioned easements as a method of long-term protection. Other methods discussed within the LDRs included conservation easements $(25 \%)$ or regulations through the homeowners' codes covenants and restrictions (CCRs) (19\%). Approximately half of the counties (46\%) required clear allocation of management responsibilities to some type of management entity. When we reviewed how long open space areas should be managed, fewer counties required long-term/perpetual management (34\%) than no time 
requirement $(65 \%)$. Only $18 \%$ of the counties required developers to submit a management plan to receive development approval. Few counties insisted that plans have clear objectives $(6 \%)$ and that major changes be approved by a regulatory entity (4\%). Few counties $(9 \%)$ mandated the provision of access to the protected areas, funding to support ongoing management activities (3\%), or highlighted consequences for not implementing management $(6 \%)$.

\subsection{County OSI and MI Scores}

Open-space index scores (OSI) ranged from 0 to 14; management index scores (MI) ranged from 0 to 10 (Table 2). The Total Policy scores were computed as a sum of the OSI and MI scores and ranged from 0 to 24 (out of 28) (Figure 1). Alachua County had the highest total score (24) followed closely by Santa Rosa County (21) (Table 2). Union, Dixie, and Miami counties had the lowest scores (0), the former two provided only select chapters for review. The open space and management indices were positively correlated $(\mathrm{r}=0.624, P<0.01)$. The standardized management scores $(\mu=0.195)$ were significantly lower than the open space index scores $\left(\mu=0.427, \mathrm{t}=10.43, P<0.001, \mathrm{CI}_{0.95} 0.187,0.276\right.$ ). There were moderate but significant positive correlations between Total Policy scores and LocCSV $(\mathrm{r}=0.298, P<0.05)$, VOTE $(\mathrm{r}=0.351, P<0.01)$ and INCOME $(\mathrm{r}=0.379, P<0.01)$. As Total Policy scores increased so did the acreage of local conservation land, the number of registered voters, and per capita income).

Table 2. Open-space index, management index, and total policy scores from highest to lowest for counties in Florida.

\begin{tabular}{cccc}
\hline County Name & Open-Space Index & Management Index & Total Policy Score \\
\hline Alachua & 14 & 10 & 24 \\
Santa Rosa & 12 & 9 & 21 \\
Martin & 11 & 8 & 19 \\
Brevard & 11 & 7 & 18 \\
Charlotte & 12 & 5 & 17 \\
Pasco & 13 & 4 & 17 \\
Lee & 9 & 7 & 16 \\
Leon & 11 & 5 & 16 \\
Hardee & 9 & 5 & 14 \\
Orange & 9 & 5 & 14 \\
Palm Beach & 8 & 6 & 14 \\
Sumter & 10 & 4 & 14 \\
Bradford & 10 & 3 & 13 \\
Broward & 9 & 4 & 13 \\
Gadsden & 10 & 3 & 13 \\
Highlands & 10 & 3 & 13 \\
Manatee & 7 & 6 & 13 \\
Marion & 8 & 5 & 13 \\
Polk & 10 & 3 & 13 \\
\hline
\end{tabular}


Table 2. Cont.

\begin{tabular}{|c|c|c|c|}
\hline County Name & Open-Space Index & Management Index & Total Policy Score \\
\hline St. Lucie & 4 & 9 & 13 \\
\hline Collier & 9 & 3 & 12 \\
\hline Indian River & 10 & 2 & 12 \\
\hline Monroe & 9 & 3 & 12 \\
\hline Jefferson & 9 & 2 & 11 \\
\hline Putnam & 8 & 3 & 11 \\
\hline Citrus & 9 & 1 & 10 \\
\hline Duval & 7 & 3 & 10 \\
\hline Franklin & 6 & 4 & 10 \\
\hline Gilchrist & 8 & 2 & 10 \\
\hline Hillsborough & 8 & 2 & 10 \\
\hline Madison & 7 & 3 & 10 \\
\hline Seminole & 9 & 1 & 10 \\
\hline Columbia & 7 & 2 & 9 \\
\hline Flagler & 8 & 1 & 9 \\
\hline Nassau $^{\mathrm{b}}$ & 7 & 2 & 9 \\
\hline Volusia & 8 & 1 & 9 \\
\hline Levy & 7 & 1 & 8 \\
\hline Liberty & 7 & 1 & 8 \\
\hline Suwannee $^{\mathrm{b}}$ & 8 & 0 & 8 \\
\hline Calhoun & 7 & 0 & 7 \\
\hline DeSoto & 7 & 0 & 7 \\
\hline Hamilton & 4 & 3 & 7 \\
\hline Lake & 7 & 0 & 7 \\
\hline Walton & 7 & 0 & 7 \\
\hline Escambia & 4 & 2 & 6 \\
\hline Okaloosa & 6 & 0 & 6 \\
\hline St. Johns & 4 & 2 & 6 \\
\hline Taylor & 6 & 0 & 6 \\
\hline Wakulla & 6 & 0 & 6 \\
\hline Baker $^{\mathrm{a}}$ & 4 & 1 & 5 \\
\hline Clay & 5 & 0 & 5 \\
\hline Glades & 5 & 0 & 5 \\
\hline Holmes & 5 & 0 & 5 \\
\hline Lafayette $^{\mathrm{b}}$ & 5 & 0 & 5 \\
\hline Pinellas & 5 & 0 & 5 \\
\hline Washington & 5 & 0 & 5 \\
\hline Osceola & 4 & 0 & 4 \\
\hline Gulf & 2 & 1 & 3 \\
\hline Hernando & 3 & 0 & 3 \\
\hline Sarasota & 3 & 0 & 3 \\
\hline Bay & 2 & 0 & 2 \\
\hline Okeechobee & 2 & 0 & 2 \\
\hline
\end{tabular}


Table 2. Cont.

\begin{tabular}{cccc}
\hline County Name & Open-Space Index & Management Index & Total Policy Score \\
\hline Hendry $^{2}$ & 1 & 0 & 1 \\
Jackson $^{\mathrm{a}}$ & 1 & 0 & 1 \\
Dixie $^{\mathrm{b}}$ & 0 & 0 & 0 \\
Miami-Dade $^{\text {Oamion }}{ }^{\mathrm{b}}$ & 0 & 0 & 0 \\
Union & 0 & 0 & 0 \\
\hline
\end{tabular}

${ }^{a}$ Analysis relied on drafts of the code; ${ }^{b}$ Select chapters were analyzed.

\section{Discussion}

More than $50 \%$ of Florida counties provided incentives for open space designation, had a definition of open space, identified allowable hardscape and recreational elements, and required clear ownership of protected areas. Almost half of the county LDRs provided incentives such as density bonuses, fast track permitting, and a shortened development review process to encourage developers set aside open space. These findings suggest that the designation of open space is at least being addressed within Florida county policies. However, the definition of open space varied considerably among the counties. It is possible that the observed diversity in open space definitions is the result of the flexible language in the Florida state statutes requiring the designation and regulation of open space with few requirements about how to implement this at the local level. While this flexibility provides local policy makers an opportunity to adapt the regulation to their individual counties, it can lead to dramatic differences in the conservation value and composition of open space between counties. For example, some counties might allow swimming pools and tennis courts in the open space and others counties might allow only natural areas for resource protection.

Few of the Florida county regulations addressed the shape or size of the designated open space or how it connects to surrounding natural areas. This omission can lead to the protection of habitat with reduced conservation value [28]. Small habitat fragments are not as effective in providing wildlife habitat as larger areas, therefore, it has been recommended that protected areas with subdivisions include at least $20 \%$ of the total developable land area $[13,26]$. Counties looking to protect areas with high conservation value through the designation of open space should ensure that LDRs address the shape, size and connectivity of the open space with this goal in mind. Sustainable development techniques in the wrong location and inappropriate form can still contribute to the degradation of both environmental and cultural communities [48].

Critics of open space protection argue that protected areas within residential developments typically preserve wetlands, floodplains, and areas that are either too expensive to develop or already protected by state regulations [26]. Only a small number of Florida counties required specifics about the type of habitat requiring protection; counties may be protecting areas already protected or even areas with low value for wildlife or conservation. Further, few county policies adequately addressed the potential human impacts on open space, from construction techniques to household behaviors. Construction activities can have a significant effect on natural areas [49]. For example, lack of signage can contribute to the encroachment of heavy machinery in the protected areas, causing the destruction of natural vegetation. Improper installment and management of silt fences can result in severe sediment 
run-off in wetland areas. Homeowners play an important role in how open space functions over the long term $[12,15,16]$. Residents make decisions about which plant species to install in their yard, whether to allow their pets to roam free, whether to feed wildlife, and how much fertilizer to use; all of these decisions can negatively affect natural areas [14,22,36,50-52]. Studies indicate that few residents understand the environmental importance of natural areas nor do they possess the expertise necessary to manage protected areas [16,20,36]. Building community support for conservation goals and awareness about natural areas can help mitigate human activities that would negatively affect sensitive areas $[12,13,53]$. Homeowners associations (HOAs) generally have the authority to enforce codes, covenants and restrictions (CCRs) which regulate how homes, yards, and neighborhoods are maintained [7,54]. HOAs can raise funds or dues to pay for education programs and other engagement activities such as removing invasive exotic plants. To encourage community land stewardship, open space LDRs should contain language that addresses the management of nearby lots and the engagement of residents.

Results indicated that Florida county LDRs do not adequately address the management of open space areas, as management scores were much lower than open space designation scores. An important regulatory measure would require developers to implement an environmental education program targeting residents residing near natural areas with high conservation value. Such educational efforts can improve the environmental knowledge, attitudes, and behaviors of homeowners [55]. Other regulatory efforts could involve the establishment of conservation easements; a legal agreement between a property owner and an easement holder (generally a government body, or land trust) [26]. Another method is the requirement of CCRs that contain environmental language that specifically addresses the care and management of natural open space and nearby built areas. CCRs can encourage practices such as land stewardship and the conservation of wildlife habitat within both open areas as well as the surrounding built areas. Both CCRs and conservation easements agreements can stipulate maintenance responsibilities for natural areas, including exotic plant removal, controlled burns, and the upkeep of walking trails, and signage within the open space [54].

Our preliminary results suggest that the Total Policy score has a positive relationship with total local conservation area (acres), per capita income and voter registration. It is therefore possible that counties with high Total Policy scores protect more acres of land than counties with low Total Policy scores. However, more research would be necessary to establish a causal relationship between these two variables. The number of registered voters within a county typically increases directly with the total county population. Therefore, the total area of open space protected in the county and the strength of the LDRs may be a function of county size. Large counties with wealthier residents probably have larger budgets, which allow for greater funds for conservation designation and management.

This study focused solely on county LDRs. It is possible that this narrow focus ignored other methods that local policy makers use to promote effective designation and long-term management of open space in the absence of strong LDR language. Future research could identify the non-regulatory tools, such as education or social marketing that have been used throughout the state to encourage open space designation and management. These tools can be incredibly important in encouraging the actual implementation of sustainable development practices, such as the designation of open space. Despite ample evidence that the presence of open space can increase the sale price of a home [3,24,26,30,32,38] financiers, developers and investors often perceive alternatives to 
conventional development as more difficult to complete, and therefore involving more risk and cost [56]. Moreover, developers cite a preference for incentives and education over regulation [57]. Therefore, increased regulation might actually result in less effective or decreased designation of open space, due to developer concerns.

We recognize that conservation regulations are not a panacea for growth management. Ineffective open space and growth management policies can result in protected areas having little to no conservation value. For example, land use controls that mandate high-density development can actually increase sprawling development [58]. Conserving small areas of open space, less than $20 \%$ of the total land area, can result in fragmented landscapes with high densities of non-native species and low densities of native species [13]. Multiple developments scattered haphazardly throughout a region, even if they contain high value open space areas, can result in habitat fragmentation [22]. To conserve high quality habitat across a county, it is probably not sufficient to concentrate only on LDRs. Counties must also consider broad land use policies that address the combination of urban open space and how it connects to conserved lands within the rural matrix.

We conclude that there is a great deal of diversity across the state of Florida in the percentage of open space that is required for protection, how counties define open space, and the allowable or prohibited activities within the open space. In particular, management requirements are found to be inadequate. There are a number of reasons that policy makers might be reluctant to create strong regulations protecting open space within private subdivisions. These include developer resistance to comply with new or restrictive policies and the perceived difficulty in implementing management practices and an effective way to evaluate the outcomes of management plans. We submit, though, that the conservation value of open space will only be maintained and enhanced over the long term when policies and procedures address not only good designs, but also appropriate environmental management of open space and nearby residential areas.

\section{Acknowledgements}

The authors would like to thank the Program for Resource Efficient Communities, University of Florida, for its support of this research. We would also like to express our sincere appreciation to all the developers and policy makers who helped us develop this project.

\section{References}

1. Sustainable Cities: Concepts and Strategies for Eco-City Development; Walter, B., Ed.; Eco-Home Media: Los Angeles, CA, USA, 1992.

2. Burchell, R.W.; Shad, N.A. A natural perspective on land use policy alternatives and consequences. In Proceedings of the National Public Policy Education Conference, Clackamas, OR, USA, 20-24 September 1998.

3. Austin, M.E. Resident perspectives of the open space conservation subdivision in Hamburg Township, Michigan. Landscape Urban Plann. 2004, 69, 245-253. 
4. Zeman, A.; Hilliker, M.; Koles, M.; Marcouiller, D. Ensuring Open Space: An Assessment of Factors that Explain State-Sponsored Land Protection Programs; Working Paper 3-1; Department of Urban and Regional Planning, University of Wisconsin-Madison: Madison, WI, USA, 2003.

5. Kollin, C. Building Greener, Building Smarter: The Winds of Change are Blowing through the Building Community, Fueled by Consumer Demand and Discerning Practitioners; American Forests: Washington, DC, USA, 2005.

6. United States Census Bureau. US Census Bureau Population Projections; Available online: http://www.census.gov/ipc/www/worldpop.html (accessed on 15 July 2008).

7. Resource efficiency in the built environment. In Proceedings of the Florida Sustainable Communities Summit, Lake Buena Vista, FL, USA, 8 February 2005; Audubon International: New York, NY, USA, 2005.

8. Brody, S.D.; Highfield, W.E. Does planning work: Testing the implementation of local environmental planning in Florida. J. Amer. Plann. Assn. 2005, 71, 159-175.

9. Carriker, R.R. Florida's Growth Management Act: An Introduction and Overview; EDIS Document FE643; Food and Resource Economics Department, Florida Cooperative Extension Service, Institute of Food and Agricultural Sciences, University of Florida: Gainesville, FL, USA, 2006.

10. Florida Legislature. The 2009 Florida Statutes; Available online: http://www.leg.state.fl.us/ statutes (accessed on 29 January 2010).

11. Arendt, R. Growing Greener: Putting Conservation into Local Plans and Ordinances; Island Press: Washington, DC, USA, 1999.

12. Hostetler, M.; Drake, D. Conservation subdivisions: A wildlife perspective. Landscape Urban Plann. 2009, 90, 95-101.

13. Lenth, B.A.; Knight, R.L.; Gilgert, W.C. Conservation value of clustered housing developments. Conserv. Biol. 2006, 20, 1445-1456.

14. Hostetler, M.E.; Jones, P.; Dukes, M.; Knowles, H.; Acomb, G.; Clark, M. With one stroke of the pen: How can extension professionals involve developers \& policymakers in creating sustainable communities? J. Ext. 2008, 46, No. 1.

15. Noiseux, K.; Hostetler, M.E. Do homebuyers want green features in their communities? Environ. Behave. 2008, doi:10.1177/0013916508326470.

16. Youngentob, K.; Hostetler, M. Is a new urban development model building greener communities? Environ. Behave. 2005, 37, 731-759.

17. Westover, P. Managing Conservation Land: The Stewardship of Conservation Areas, Wildlife Sanctuaries, and Open Space in Massachusetts; Society of Municipal Conservation Professionals: Belmont, MA, USA, 1994.

18. Wilson, A.; Uncapher, J.L.; McManigal, L.; Lovins, L.H.; Cureton, M.; Browning, W.D. Green Development: Integrating Ecology and Real Estate; John Wiley and Sons: New York, NY, USA, 1998.

19. Romero, M.; Hostetler, M.E. Policies that Address Sustainable Site Development; University of Florida: Gainesville, FL, USA, 2007; CIR1520. 
20. Milder, J.C.; Lassoie, J.P.; Bedford, B.L. Conserving biodiversity and ecosystem function through limited development: An empirical evaluation. Conserv. Biol. 2008, 22, 70-79.

21. Odell, E.A.; Theobald, D.M.; Knight, R.L. Incorporating ecology into land use planning: The Songbirds' case for clustered development. J. Am. Plann. Assoc. 2003, 69, 72-82.

22. Theobald, D.M.; Miller, J.R.; Hobbs, N.T. Estimating the cumulative effects of development on wildlife habitat. Landscape Urban Plann. 1997, 39, 25-36.

23. Getting to Smart Growth: 100 Policies for Implementation; Smart Growth Network: Washington, DC, USA, 2002.

24. Lichtenberg, E.; Tra, C.; Hardie, I. Land use regulation and the provision of open space in suburban residential subdivisions. J. Environ. Econ. Manage. 2007, 54, 199-213.

25. Reichert, A.K.; Liang, H. An economic analysis of real estate conservation subdivision developments. Appraisal J. 2007, 75, 236-245.

26. Wenger, S.; Fowler, L. Community Choices Toolkit: Conservation Subdivisions; Atlanta Regional Commission and Georgia Department of Community Affairs: Atlanta, GA, USA, 2002.

27. Marzluff, J.M. Restoration of fragmented landscapes for the conservation of birds: A general framework and specific recommendations for urbanizing landscapes. Restor. Ecol. 2001, 9, 280-292.

28. Milder, J.C. A framework for understanding conservation development and its ecological implications. Bioscience 2007, 57, 757-768.

29. Perlman, D.L.; Milder, J.C. Practical Ecology for Planners, Developers, and Citizens; Island Press: Washington, DC, USA, 2005.

30. Luttik, J. The value of trees, water and open space as reflected by house prices in The Netherlands. Landscape Urban Plann. 2000, 48, 161-167.

31. Land Vote 2001: Americans Invest in Parks and Open Space; The Trust for Public Land: San Francisco, CA, USA; Land Trust Alliance: Washington, DC, USA, 2001.

32. Lacy, J. An Examination of Market Appreciation for Clustered Housing with Permanent Open Space; University of Massachusetts-Amherst: Amherst, MA, USA, 1990.

33. Gilroy, L. Conservation Design: A Market-Friendly Approach to Local Environmental Protection; Reason Foundation: Los Angeles, CA, USA, 2006.

34. Mohamed, R. The economics of conservation subdivisions: Price premiums, improvement costs, and absorption rates. Urban Aff. Rev. 2006, 41, 376-399.

35. Peck, S. Planning for Biodiversity: Issues and Examples; Island Press: Washington, DC, USA, 1998.

36. Thompson, R.H. Overcoming barriers to ecologically sensitive land management: Conservation subdivisions, green developments, and the development of a land ethic. J. Plan. Educ. Res. 2004, $24,141-153$.

37. Ecosystems of Florida; Meyers, R.L., Ewel, J.J., Eds.; University of Florida Press: Orlando, FL, USA, 1990.

38. Arendt, R. Conservation Design for Subdivisions: A Practical Guide to Creating Open Space Networks; Island Press: Washington, DC, USA, 1996. 
39. Arendt, R. Linked landscapes: Creating greenway corridors through conservation subdivision design strategies in the northeastern and central United States. Landscape Urban Plann. 2004, 68, 241-269.

40. Culliney, T.W. Benefits of classical biological control for managing invasive plants. Crit. Rev. Plant Sci. 2005, 2, 131-150.

41. Feiock, R.C.; Tavares, A. County government institutions and local land regulation. In Proceedings of the International Seminar on Analysis of Urban Land Markets and the Impact of Land Market Regulation, Lincoln Institute of Land Policy, Cambridge, MA, USA, July 2002.

42. Golgowski, G. Harmony Florida, Osceola County, FL, USA. Personal communication, 2006.

43. Municipal Code Corporation Municode Library Homepage. http://www.municode.com/Library/ library.aspx (accessed on 28 February 2010).

44. Riffe, D.; Lacy, A.F. Analyzing Media Messages: Using Quantitative Content Analysis in Research; Laurence Erlbaum Associates: Mahway, NJ, USA, 1998.

45. Holsti, O.R. Content Analysis for the Social Sciences and Humanities; Addison-Wesley: Reading, MA, USA, 1969.

46. Agresti, A.; Finlay, B. Statistical Methods for the Social Sciences; Pearson Prentice Hall: Upper Saddle River, NJ, USA, 2009.

47. Hayes, A.F.; Krippendorf, K. Answering the call for a standard reliability measure for coding data. Commun. Method. Measure. 2007, 1, 77-89.

48. Berke, P.R.; Conroy, M.M. Are we planning for sustainable development? J. Am. Plann. Assoc. 2000, 66, 21-33.

49. Hostetler, M.E. Beyond design: The importance of construction and post-construction phases in green developments. Sustainability 2010, 2, 1128-1137.

50. Miller, J.R.; Hobbs, N.T. Recreational trails, human activity, and nest predation in lowland riparian areas. Landscape Urban Plann. 2000, 50, 227-236.

51. Baker, P.J.; Bentley, A.J.; Ansell, R.J.; Harris, S. Impact of predation by domestic cats Felis catus in an urban area. Mammal Rev. 2005, 35, 302-312.

52. Pimentel, D.; McNair, S.; Janecka, J.; Wightman, J.; Simmonds, C.; O’Connell, C.; Wong, E.; Russel, L.; Zern, J.; Aquino, T.; Tsomondo, T. Economic and environmental threats of alien plant, animal, and microbe invasions. Agric. Ecosyst. Environ. 2001, 84, 1-20.

53. Hostetler, M.E.; Duncan, S.; Paul, J. Post-construction effects of an urban development on migrating, resident, and wintering birds. Southeast. Nat. 2005, 4, 421-434.

54. Hostetler, M.E. Evaluating Green Communities: Top Eleven Questions to Ask; Department of Wildlife Ecology and Conservation, Florida Cooperative Extension Service, Institute of Food and Agricultural Sciences (IFAS), University of Florida: Gainesville, FL, USA, 2006.

55. Hostetler, M.; Swiman, E.; Prizzia, A.; Noiseux, K. Reaching residents of green communities: Evaluation of a unique environmental education program. Appl. Environ. Educ. Commun. 2008, 7, 114-124.

56. Gyourko, J.; Rybczynski, W. Financing new urbanism projects: Obstacles and solutions. Housing Policy Debate 2000, 11, 733-750.

57. Wright, D.W. Infrastructure planning and sustainable development. J. Urban Plan. Dev.-Asce. 1996, 122, 111-117 
58. Pendall, R. Do land-use controls cause sprawl? Environ. Plan. B: Plan. Design 1999, 16, 555-571.

(C) 2010 by the authors; licensee MDPI, Basel, Switzerland. This article is an Open Access article distributed under the terms and conditions of the Creative Commons Attribution license (http://creativecommons.org/licenses/by/3.0/). 